\title{
LABORATORY STUDY ON MACRO-FEATURES OF WAVE BREAKING OVER BARS AND ARTIFICIAL REEFS
}

\author{
by \\ Ernest R. Smith, Nicholas C. Kraus \\ Coastal Engineering Research Center \\ DEPARTMENT OF THE ARMY
}

Waterways Experiment Station, Corps of Engineers

3909 Halls Ferry Road, Vicksburg, Mississippi 39180-6199

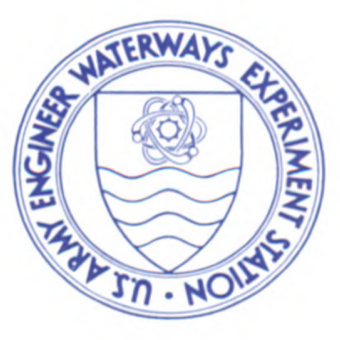

July 1990

Final Report

Approved For Public Release; Distribution Unlimited

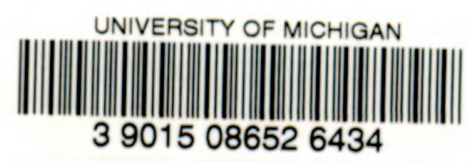

Prepared for DEPARTMENT OF THE ARMY

US Army Corps of Engineers

Washington, DC 20314-1000

Under Nearshore Waves and Currents

Work Unit 31672 